\title{
Occurrence of Insecticide Residues in Selected Crops and Natural Resources
}

\author{
B. Ratna Kumari • G. V. Ranga Rao • \\ K. L. Sahrawat $\cdot$ P. Rajasekhar
}

Received: 11 January 2012/Accepted: 9 April 2012/Published online: 28 April 2012

(C) Springer Science+Business Media, LLC 2012

\begin{abstract}
Pesticide residue monitoring was taken up at Kothapally and Enkepally villages of Ranga Reddy district, Andhra Pradesh in food crops (rice, maize, pigeonpea), vegetables (tomato and brinjal), cotton besides soil and water during 2008-2009 seasons. Of the 80 food crop and cotton samples, only two rice grain samples $(3 \%)$ showed beta endosulfan residues and two (3\%) out of 80 soil samples of food crops and cotton showed alpha and beta endosulfan residues. Out of 75 tomato samples, 26 (35\%) were contaminated and $4 \%$ had residues above maximum residue limit (MRLs). Out of the 50 soil samples from tomato fields, 13 (26\%) contained residues. Among the 80 brinjal samples, $46(56 \%)$ contained residues and $4 \%$ of samples had residues above MRLs. Only $13 \%$ of the soil samples from brinjal fields were contaminated. Water samples found free from residues. In general the incidence of residues was below MRL in food crops.
\end{abstract}

Part of Ph.D. thesis submitted to ANGRAU, Andhra Pradesh, India.

B. Ratna Kumari $(\bowtie) \cdot$ G. V. Ranga Rao · K. L. Sahrawat International Crop Research Institute for Semi arid Tropics (ICRISAT), Patancheru, Hyderabad 502 324, Andhra Pradesh, India

e-mail: ratnabhimineni@yahoo.com

G. V. Ranga Rao

e-mail: g.rangarao@cgiar.org

K. L. Sahrawat

e-mail: k.sahrawat@cgiar.org

P. Rajasekhar

Agricultural Research Station, Nellore 524 003, Andhra Pradesh, India

e-mail:pachipala007@yahoo.com
Keywords Pesticide residues · Food crops - Vegetables · Soil $\cdot$ Water $\cdot$ MRLs

Excessive and non-judicious use of insecticides has led to the degradation of environmental quality, pest resistance, pest resurgence and the contamination of agricultural products and natural resources. Most of the studies on pesticides taken up in India reflect the presence of pesticide residues in significant amounts in food and agricultural commodities, and pesticide pollution does exist in the country and is a cause of concern for public health (Kumari et al. 2002, 2003, 2004, 2005, 2006). Pesticides applied at the soil or those those end in the soil in agricultural areas can contribute to the contamination of surface and ground waters (Gilliom et al. 2006; McMahon et al. 2006). The safety of agricultural chemicals used worldwide must be tested both locally and internationally and then only they should be approved for use if they pose no greater risk to the consumers than the foods grown without their use. In view of these problems, this study was undertaken to monitor the insecticide residues in different crops, soil and water.

\section{Materials and Methods}

The residues of monocrotophos, chlorpyriphos, endosulfan and cypermethrin insecticides in food crops (rice, maize, and pigeonpea), cotton, vegetables (tomato and brinjal) besides soil and water samples were monitored in Kothapally and Enkepally villages of Ranga Reddy district (semi-arid tropical watershed) of India during 2008-2009 seasons under farmer's insect pest management practices. Prior to conducting the monitoring study, participatory 
rural appraisal (PRA) was undertaken in the two villages to generate information on the existing plant protection practices and elicit farmers' views on plant protection approaches used. The major insecticides chosen for residue monitoring in crops, soil and water were those that were widely used and popular among the farmers as indicated during the PRA survey.

During the Rabi (post-rainy - November/December/ January/February) 2008 and 2009 seasons, five kilograms of grain samples from five different locations were collected from 10 fields each of rice, maize, pigeonpea and in the case of cotton crop, five kilograms of 10 lint samples were collected at the time of harvest. Similarly, 10 soil (At each site, two soil plugs of about $15 \mathrm{~cm}$ deep and 3-5 cm diameter in grid pattern) and 10 ground water (Three liters from bore wells and open wells samples) samples from the selected fields were collected at the starting and end of the season. One to two kilograms of tomato and brinjal fruits from 10 randomly selected areas were collected at monthly intervals thrice and four times during the crop period respectively during Summer (March/April/May/June), Kharif (July/August/September/October/November) and Rabi, 2008 and Summer and Kharif, 2009 seasons.

Method used for the residue extraction from the samples was that based on multi-insecticide residues as several compounds could be targeted simultaneously. Rice was pounded to separate grains from bran while maize grains were obtained by removal of husk. Pigeonpea grains were collected after removing pod cover. Extraction of grain, vegetable, soil and water samples was carried out following the procedures of Luke and Doose (1983), Vicente and Yolando (2004) and Hernandez et al. (1993), respectively. Clean up of the extract was done with solid phase extraction (SPE)-FL PR (florisil) cartridges fitted to SPE vacuum manifold (from Phenomenex Company). The eluant was concentrated to $2 \mathrm{~mL}$ with nitrogen gas purging, and analyzed for the presence of insecticide residues using Gas Chromatography-Mass Spectrometer (Schimadzu Model GC-MS QP 5050A).

The insecticide reference standards were purchased from Dr. Ehrenstorfer, Augsburg, Germany and the purity range of standards ranged from $96 \%$ to $99.0 \%$. The standard mixtures of analytes were prepared at $0.5,0.2,0.1$, 0.05 and $1.0 \mu \mathrm{g} \mathrm{mL}^{-1}$ concentrations by serial dilution technique for preparing the calibration curve. All the standards were always stored in refrigerator at $4^{\circ} \mathrm{C}$.

GC-17A Ver.3 equipped with mass spectrometer detector and Zebron Multi residue column ZB -1, with $30 \times 0.25 \mathrm{~mm}$ i.d. (internal diameter) and $0.25 \mu \mathrm{m}$ thickness of $100 \%$ dimethylpolysiloxane stationary phase was used. GC operating parameters were as follows: Carrier gas- Helium; Column inlet pressure $-130.1 \mathrm{kPa}$; Column

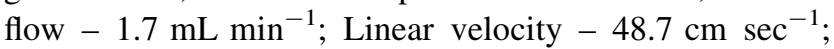

Split ratio -0 ; Total flow $-3 \mathrm{~mL} \mathrm{~min}^{-1}$; Carrier flow $-3 \mathrm{~mL} \mathrm{~min}^{-1}$. The column was initially maintained at $110^{\circ} \mathrm{C}$ for $3 \mathrm{~min}$, and the temperature was increased at the rate of $15^{\circ} \mathrm{C}$ per min up to $280^{\circ} \mathrm{C}$. The column was held at $280^{\circ} \mathrm{C}$ for $2 \mathrm{~min}$ and then the temperature was increased at the rate of $30^{\circ} \mathrm{C}$ per min and finally increased to $300^{\circ} \mathrm{C}$, at the rate of $30^{\circ} \mathrm{C} \mathrm{min}{ }^{-1}$ and held for 4 min to facilitate separation of all the compounds. The mass spectrometer was calibrated weekly. The individual insecticide standards were run in scan mode and then in selected ion monitoring (SIM) mode using two or three reference ions with total program time of $22.67 \mathrm{~min}$.

Mass spectrometer parameter used are as follows: Acquisition mode - SIM; Micro scan width - 0; Interface temperature $-260^{\circ} \mathrm{C}$; Solvent cut time $-8.5 \mathrm{~min}$ Detector voltage - $0.1 \mathrm{kv}$; Threshold - 1,000; Interval - $0.5 \mathrm{~s}$; GC program time $-22.67 \mathrm{~min}$. A calibration curve or linearity curve was formed using the standard areas and retention times. The insecticide residues were estimated by injecting $1 \mu \mathrm{L}$ volume of extracted and cleaned samples in GC-MS. Based on the area of peaks obtained at the particular retention time and target and qualifier ions, which matched with those of standards, insecticide residue concentration was calculated.

Recovery studies were made at two concentrations of $0.01 \mu \mathrm{g} \mathrm{g}^{-1}$ (LOQ - Limit of quantification) and $0.025 \mu \mathrm{g} \mathrm{g}^{-1}$ (2.5 times of LOQ) in food crops and cotton lint. Spiking was done at LOQ level of $0.005 \mu \mathrm{g} \mathrm{g}^{-1}$ and five times of LOQ in vegetables (tomato and brinjal) and soil at $0.001 \mu \mathrm{g} \mathrm{mL}^{-1}$ (LOQ) and $0.0005 \mu \mathrm{g} \mathrm{mL}^{-1}$ (five times of LOQ) in water.

\section{Results and Discussion}

The GC-MS response for all analytes was linear in the concentration range $\left(0.05-1.0 \mu \mathrm{g} \mathrm{mL}^{-1}\right)$ assayed with

Table 1 Insecticide residues ( $\mu \mathrm{g} \mathrm{g}^{-1}$ ) in food crops, cotton, soil from Kothapally and Enkepally during 2008 and 2009 seasons

\begin{tabular}{|c|c|c|c|}
\hline Crop & Year & Grain/lint & Soil \\
\hline \multirow[t]{2}{*}{ Rice } & 2008 & $\begin{array}{l}\text { Beta endosulfan } \\
\left(0.5 \mu \mathrm{g} \mathrm{g}^{-1}\right)\end{array}$ & - \\
\hline & 2009 & $\begin{array}{l}\text { Beta endosulfan } \\
\quad\left(0.008 \mu \mathrm{g} \mathrm{g}^{-1}\right)\end{array}$ & - \\
\hline \multirow[t]{2}{*}{ Maize } & 2008 & - & $\begin{array}{l}\text { Alpha endosulfan } \\
\left(0.02 \mu \mathrm{g} \mathrm{g}^{-1}\right) \\
\text { Beta endosulfan } \\
\left(0.02 \mu \mathrm{g} \mathrm{g}^{-1}\right)\end{array}$ \\
\hline & 2009 & - & - \\
\hline \multirow[t]{2}{*}{ Pigeonpea } & 2008 & - & - \\
\hline & 2009 & - & - \\
\hline \multirow[t]{2}{*}{ Cotton } & 2008 & - & - \\
\hline & 2009 & - & - \\
\hline
\end{tabular}


correlation coefficients $>0.998$. Recoveries obtained for all the analytes varied from $84.62 \%$ to $117.92 \%$ with relative standard deviation (RSD) between 0.39 and 9.90. The data (Table 1) showed that out of all grain samples analyzed, one sample of rice grain was contaminated with beta endosulfan $\left(0.5 \mu \mathrm{g} \mathrm{g}^{-1}\right)$. Alpha $\left(0.02 \mu \mathrm{g} \mathrm{g}^{-1}\right)$ and beta endosulfan $\left(0.02 \mathrm{\mu g} \mathrm{g}^{-1}\right)$ residues were detected in one soil sample collected from maize field during 2008 season. Only two samples contained beta endosulfan residue - one rice grain sample $\left(0.008 \mu \mathrm{g} \mathrm{g}^{-1}\right)$ and one soil sample collected from rice field $\left(0.03 \mu \mathrm{g} \mathrm{g}^{-1}\right)$ during the 2009 season. However, none of the pigeonpea grain and cotton lint samples were contaminated with insecticide residues. The presence of endosulfan residues in rice grain and soil from rice field could be attributed to the fact that farmers used endosulfan for pest control in the Paddy fields, which was evident from the results of our survey. Our results are also supported by the findings of Battu et al. (1989), Kannathasan and Regupathy (1992), Ahuja and Awasthi (1993) who reported that organochlorine residues $(\mathrm{HCH}$,
DDT) did exist in rice grains and soils from rice plots at the harvest time.

Detection of residues in soil from maize fields was in consonance with the results of the study conducted by Singh et al. (1992) who reported that the residues of endosulfan in maize cobs were below the detectable level. Senapati et al. (1992) reported no presence of endosulfan residues in pigeonpea grain at harvest. Samant et al. (1997) and Nayak et al. (2004) also reported non-detectable levels of chlorpyriphos and endosulfan on the harvested grain of blackgram and greengram. The non detection of residues in soils from pigeonpea fields are in agreement with the results of Tanwar and Handa (1998). A shift in cotton cultivation from traditional to Bt varieties, which requires less number of sprays according to our survey might be one of the reason for non-detectable residues in cotton lint. Suganya Kanna et al. (2007) also found that the residues of imidacloprid and acetamiprid in cotton lint were below the detectable levels.

The data on insecticide residues in tomato fruits and soil are presented in Table 2. Out of the 15 tomato fruit

Table 2 Insecticide residues in tomato fruit and soil samples from Kothapally and Enkepally villages during 2008 and 2009 seasons

\begin{tabular}{|c|c|c|c|c|c|c|}
\hline \multirow[t]{2}{*}{ Season } & \multicolumn{2}{|c|}{ No. of samples } & \multirow{2}{*}{$\begin{array}{l}\text { Insecticides } \\
\text { detected }\end{array}$} & \multirow[t]{2}{*}{ Frequencies } & \multirow{2}{*}{$\begin{array}{l}\text { Residue } \\
\text { level }\left(\mu \mathrm{g} \mathrm{g}^{-1}\right)\end{array}$} & \multirow{2}{*}{$\begin{array}{l}\text { MRL } \\
\left(\mu g^{-1}\right)^{a}\end{array}$} \\
\hline & Analyzed & Contaminated & & & & \\
\hline Summer, 2008 & 15 & 8 & Monocrotophos & 3 & $0.2,0.2,0.3$ & 0.2 \\
\hline \multirow[t]{3}{*}{ Fruit } & & & Alpha endosulfan & 2 & $0.04,0.01$ & 2.0 \\
\hline & & & Beta endosulfan & 3 & $0.04,0.03,0.04$ & 2.0 \\
\hline & & & Cypermethrin & 4 & $0.2,0.04,0.1,0.06$ & 0.5 \\
\hline Soil & 10 & 3 & Cypermethrin & 3 & $0.1,0.3,0.01$ & \\
\hline Kharif, 2008 & 15 & 6 & Monocrotophos & 2 & $0.006,0.009$ & 0.2 \\
\hline \multirow[t]{2}{*}{ Fruit } & & & Beta endosulfan & 3 & $0.03,0.02,0.008$ & 2.0 \\
\hline & & & Cypermethrin & 3 & $0.08,0.3,0.07$ & 0.5 \\
\hline \multirow[t]{2}{*}{ Soil } & 10 & 5 & Alpha endosulfan & 2 & $0.05,0.02$ & \\
\hline & & & Beta endosulfan & 3 & $0.02,0.07,0.04$ & \\
\hline Rabi, 2008 & 15 & 1 & Alpha endosulfan & 1 & 0.07 & 2.0 \\
\hline \multicolumn{7}{|l|}{ Fruit } \\
\hline Soil & 10 & 1 & Beta endosulfan & 1 & 0.03 & \\
\hline Summer, 2009 & 15 & 7 & Monocrotophos & 4 & $0.01,0.1,0.09,0.05$ & 0.2 \\
\hline \multirow[t]{3}{*}{ Fruit } & & & Alpha endosulfan & 2 & $0.2,0.09$ & 2.0 \\
\hline & & & Beta endosulfan & 2 & $0.4,0.03$ & 2.0 \\
\hline & & & Cypermethrin & 3 & $0.08,0.05,0.08$ & 0.5 \\
\hline \multirow[t]{2}{*}{ Soil } & 10 & 3 & Alpha endosulfan & 2 & $0.05,0.8$ & \\
\hline & & & Cypermethrin & 1 & 0.04 & \\
\hline Kharif, 2009 & 15 & 4 & Monocrotophos & 1 & 0.06 & 0.2 \\
\hline \multirow[t]{2}{*}{ Fruit } & & & Alpha endosulfan & 1 & 0.06 & 2.0 \\
\hline & & & Cypermethrin & 1 & 0.5 & 0.5 \\
\hline Soil & 10 & 1 & Beta endosulfan & 1 & 0.2 & \\
\hline Total Fruit samples & 75 & 26 & & & & \\
\hline Total soil samples & 50 & 13 & & & & \\
\hline
\end{tabular}

${ }^{a}$ MRLs not available for insecticide residues in soils 
Table 3 Insecticide residues in brinjal fruit and soil samples from Kothapally and Enkepally during 2008 and 2009 seasons

\begin{tabular}{|c|c|c|c|c|c|c|}
\hline \multirow[t]{2}{*}{ Season } & \multicolumn{2}{|c|}{ No. of samples } & \multirow{2}{*}{$\begin{array}{l}\text { Insecticides } \\
\text { detected }\end{array}$} & \multirow[t]{2}{*}{ Frequencies } & \multirow[t]{2}{*}{ Residue level $\left(\mu \mathrm{g} \mathrm{g}^{-1}\right)$} & \multirow{2}{*}{$\begin{array}{l}\text { MRL } \\
\left(\mu \mathrm{g} \mathrm{g}^{-1}\right)^{\mathrm{a}}\end{array}$} \\
\hline & Analyzed & Contaminated & & & & \\
\hline Summer, 2008 & 16 & 9 & Monocrotophos & 5 & $0.02,0.06,0.1,0.06,0.1$ & 0.2 \\
\hline \multirow[t]{4}{*}{ Fruit } & & & Chlorpyriphos & 2 & $0.009,0.009$ & 0.2 \\
\hline & & & Alpha endosulfan & 4 & $1.0,0.9,1.0,0.9$ & 2.0 \\
\hline & & & Beta endosulfan & 5 & $1.0,3.0,0.07,1.0,3.0$ & 2.0 \\
\hline & & & Cypermethrin & 6 & $0.07,0.1,0.05,0.02,0.05,0.02$ & 0.2 \\
\hline \multirow[t]{2}{*}{ Soil } & 8 & 2 & Monocrotophos & 1 & 0.06 & \\
\hline & & & Chlorpyriphos & 1 & 0.03 & \\
\hline Kharif, 2008 & 16 & 11 & Monocrotophos & 6 & $0.2,0.03,0.01,0.01,0.09,0.006$ & 0.2 \\
\hline \multirow[t]{3}{*}{ Fruit } & & & Alpha endosulfan & 2 & $0.06,0.01$ & 2.0 \\
\hline & & & Beta endosulfan & 1 & 0.02 & 2.0 \\
\hline & & & Cypermethrin & 6 & $0.05,0.05,0.1,0.04,0.01,0.09$ & 0.2 \\
\hline Soil & 8 & - & - & - & - & \\
\hline Rabi, 2008 & 16 & 7 & Monocrotophos & 5 & $0.03,0.09,0.009,0.09,0.009$ & 0.2 \\
\hline \multirow[t]{2}{*}{ Fruit } & & & Alpha endosulfan & 2 & $0.06,0.06$ & 2.0 \\
\hline & & & Cypermethrin & 5 & $0.05,0.009,0.1,0.009,0.1$ & 0.2 \\
\hline \multirow[t]{2}{*}{ Soil } & 8 & 1 & Alpha endosulfan & 1 & 0.1 & \\
\hline & & & Cypermethrin & 1 & 0.02 & \\
\hline \multirow[t]{4}{*}{ Summer, 2009} & 16 & 11 & Monocrotophos & 5 & $0.2,0.01,0.03,0.01,0.03$ & 0.2 \\
\hline & & & Alpha endosulfan & 7 & $0.01,0.07,0.009,0.01,0.07,0.009,0.01$ & 2.0 \\
\hline & & & Beta endosulfan & 4 & $0.006,0.08,0.006,0.08$ & 2.0 \\
\hline & & & Cypermethrin & 4 & $0.03,0.2,0.02$ & 0.2 \\
\hline Soil & 8 & 1 & Beta endosulfan & 1 & 0.01 & \\
\hline Kharif, 2009 & 16 & 8 & Monocrotophos & 1 & 0.02 & 0.2 \\
\hline \multirow[t]{4}{*}{ Fruit } & & & Chlorpyriphos & 1 & 0.01 & 0.2 \\
\hline & & & Alpha endosulfan & 2 & $0.06,2.0$ & 2.0 \\
\hline & & & Beta endosulfan & 2 & $0.05,0.9$ & 2.0 \\
\hline & & & Cypermethrin & 5 & $0.1,0.03,0.02,0.2,0.1,0.06$ & 0.2 \\
\hline Soil & 8 & 1 & Cypermethrin & 1 & 0.07 & \\
\hline Total fruit samples & 80 & 46 & & & & \\
\hline Total soil samples & 40 & 5 & & & & \\
\hline
\end{tabular}

${ }^{a}$ MRLs not available for insecticide residues in soils

samples analyzed during the 2008 summer season from two villages, eight (53\%) samples were found to be contaminated with all the insecticide groups under study, except for chlropyriphos and the residue concentration ranged from 0.01 to $0.3 \mu \mathrm{g} \mathrm{g}^{-1}$. However, one sample showed monocrotophos residue above the MRL. During the Kharif 2008 season, $40 \%$ of the samples (6 out of 15 ) were contaminated $\left(0.006-0.3 \mu \mathrm{g} \mathrm{g}^{-1}\right)$. One $\left(0.07 \mu \mathrm{g} \mathrm{g}^{-1}\right)$ out of the 15 samples contained insecticide residues during the Rabi, 2008 season. During the 2009 summer season, low concentrations of residues in 7 out of 15 samples (47\%) were detected showing monocrotophos as the major insecticide. Four samples out of 15 contained residues during the 2009 Kharif season. Residues were within the prescribed MRLs in 2009 summer and Kharif seasons (Table 2). Out of the
10 soil samples $3(33 \%)$ contained cypermethrin residue (0.1-0.3 $\left.\mu \mathrm{g} \mathrm{g}^{-1}\right)$ during the 2008 summer season. Alpha and beta endosulfan residues $\left(0.02-0.07 \mu \mathrm{g} \mathrm{g}^{-1}\right)$ in 5 out (55\%) of 10 samples were detected during 2008 Kharif season. During the 2008 Rabi, only 1 out of 10 soil samples contained beta endosulfan residue $\left(0.03-0.2 \mu \mathrm{g} \mathrm{g}^{-1}\right)$. Three out of ten soil samples contained alpha endosulfan and cypermethrin residues (0.04-0.8 $\left.\mathrm{gg} \mathrm{g}^{-1}\right)$ during the 2009 Kharif season.

In brinjal during 2008 summer season, the frequency of contamination was high with cypermethrin (0.009$3.0 \mu \mathrm{g} \mathrm{g}^{-1}$ ) in 9 out of 16 brinjal fruit samples. Beta endosulfan was present in greater concentration $\left(3.0 \mu \mathrm{g} \mathrm{g}^{-1}\right)$ and was above the MRL (Table 3). A contamination level of $69 \%$ (11 out of 16) with monocrotophos and cypermethrin 
as the main contaminants $\left(0.006-0.2 \mu \mathrm{g} \mathrm{g}^{-1}\right)$. In 7 out of 16 samples, residues of monocrotophos, alpha endosulfan and cypermethrin (44\% contamination) were detected during 2008 Rabi season, $\left(0.009-0.1 \mu \mathrm{g} \mathrm{g}^{-1}\right)$. Sixty nine per cent (11 out of 16) of the samples were contaminated during 2009 summer season and the concentration ranged from 0.006 to $0.2 \mu \mathrm{g} \mathrm{g}^{-1}$. In 8 out of 16 samples ( 0.01 to $2.0 \mu \mathrm{g} \mathrm{g}^{-1}$ ) insecticide residues were detected during the 2009 Kharif season. The results on soil analysis were shown in Table 3 . Monocrotophos $\left(0.06 \mu \mathrm{g} \mathrm{g}^{-1}\right)$ and chlorpyriphos $\left(0.03 \mu \mathrm{g} \mathrm{g}^{-1}\right)$ residues were detected in the samples collected in 2008 summer season. During the 2008 Kharif season, insecticide residues were not detected in the samples. One out of the eight $(13 \%)$ samples collected contained the residues of different insecticides $\left(0.01-0.1 \mu \mathrm{g} \mathrm{g}^{-1}\right)$ during the 2008 Rabi, 2009 summer and 2009 Kharif seasons. Analysis of water samples collected from open wells and bore wells, used for irrigation of food crops and vegetable crops contained insecticide residues at not detectable levels during various seasons in 2008 and 2009.

The presence of monocrotophos in selected vegetable samples in concentrations above the MRL probably due to unauthorized sale by pesticide dealers and their use by farmers, although this insecticide was banned for use on vegetables as per the Insecticide Act, 1968 as on 28th December, 2006 (Sharma 2007). The contamination of soil samples with insecticide residues from the field planted with brinjal was lower as compared to the samples from the field planted with tomato. This could be attributed to greater canopy cover under brinjal and longer duration of the crop. Jayashree and Vasudevan (2007) indicated that high cover by the paddy canopy could lose greater concentrations of pesticide in soil and pesticide load in the runoff.

No water sample collected from food crop fields and vegetable fields showed insecticide residues. This could be attributed to the hydrophobicity of the organochlorines and pyrethroids. According to the WHO (2004), most of the organochlorine pesticides are practically insoluble in water. Our results are in agreement with the findings of Jagdishwar Reddy et al. (1997) who reported no insecticide residues in river, tank and canal water. However, most of the documented review on pesticide residues in water in India indicated the presence of highly persistent organochlorines like DDT, $\mathrm{HCH}$, lindane, and heptachlor and endosulfan in different water sources. The suspended residues were severely dealt with by the percolating Sunrays and decomposed rapidly through photo degradation reaction and hence pyrethroids did not persist longer in the surface or bottom water layers (Awasthi 1997).

As majority of the samples in the present study were found to contain residues at non-detectable levels or at concentrations less than MRLs of the respective insecticides, the present pattern of insecticide use in vegetable fields in both Kothapally and Enkepally does not seem to contribute towards excessive insecticide residues.

Acknowledgments This work was supported by ICRISAT, Patancheru, Hyderabad, Andhra Pradesh, India and ANGRAU, Rajendranagar, Andhra Pradesh, Hyderabad.

\section{References}

Ahuja AK, Awasthi MD (1993) Contamination of rice and wheat grains with residues of $\mathrm{HCH}$ and DDT. Pesticide Research Journal 5(1):83-86

Awasthi MD (1997) Degradation and persistence of synthetic pyrethroids in tropical soil and aquatic environment. Indian $\mathbf{J}$ Environ Toxicol 7(1):36-38

Battu RS, Singh PP, Kapoor SK, Singh B, Kalra RL (1989) Residue implications of using technical $\mathrm{HCH}$ on Rice crop in Punjab. Pesticide Research Journal 1(2):67-71

Gilliom RJ, Barbash CG, Crawford PA, Hamilton JD, Martin N, Nakagaki LH, Nowell JC, Scott PE, Stackelberg GP, Thelin A, Wolock DM (2006) The quality of our nation's waters-Pesticides in the Nation's streams and ground water, 1992-2001. Circ. 1291. USGS, Washington, DC. Available at http://ca.water.usgs. gov/pnsp/pubs/circl1291/

Hernandez F, Beltran J, Sancho JV (1993) Study of multi-residue methods for the determination of selected pesticides in groundwater. Sci Total Environ 132:297-312

Jagdishwar Reddy D, Narasimha Rao B, Narasimha Reddy K, Sultan MA, Ramesh Babu T (1997) Monitoring of pesticide residues in river, tank and canal water. Pestic Res J 9(1):97-100

Jayashree R, Vasudevan N (2007) Organochlorine pesticide residues in ground water of Thiruvallur district, India. Environ Monit Assess 128:209-215

Kannathasan M, Regupathy A (1992) Monitoring of HCH, DDT and Malathion in rice from Tamil Nadu. Pesticide Research Journal 4(2):133-135

Kumari B, Madan VK, Kumar R, Kathpal TS (2002) Monitoring of seasonal vegetables for pesticide residues. Environ Monit Assess 74:263-270

Kumari B, Gulati R, Kathpal TS (2003) Monitoring of pesticidal contamination in honey. Korean J Apic 18(2):155-160

Kumari B, Madan VK, Singh J, Singh S, Kathpal TS (2004) Monitoring of pesticidal contamination of farmgate vegetables from Hisar. Environ Monit Assess 90:65-77

Kumari B, Singh J, Singh S, Kathpal TS (2005) Monitoring of butter and ghee (clarified butter fat) for pesticidal contamination from cotton belt of Haryana, India. Environ Monit Assess 105:111120

Kumari B, Madan VK, Kathpal TS (2006) Monitoring of pesticide residues in fruits. Environ Monit Assess 123:407-412

Luke MA, Doose GM (1983) Bulletin of Environmental Contamination and Toxicology 30:110-116

McMahon PB, Dennehy KF, Bruce BW, Bohlke JK, Michel RL, Grudak JJ, Hurlbut DB (2006) Storage and transit time of chemicals in thick unsaturated zones under rangeland and irrigated cropland, high plains, United States. Water Resour Res 42:W03413. doi:10.1029/2005WR004417

Nayak SK, Chhibber RC, Ujagir R (2004) Residue of endosulfan in harvested grains of Blackgram (Vigna mungo L.) protected during different growth stages. Insect Environ 10(2):68

Samant P, Senapati HK, Pal AK, Pattnaik MR, Swain N (1997) Persistence of chlorpyriphos in greengram and blackgram. Pestic Res J 9(2):261-262 
Senapati HK, Sahoo BK, Pattnaik MR, Pal AK (1992) Persistence of some common pesticides in pigeonpea. Orissa J Agric Res 5(1-2):100-103

Sharma KK (2007) Pesticides registered/banned/restricted in India. Pestic Res Anal Man:171-176

Singh YP, Gangwar SK, Thakur NSA (1992) Persistence of endosulfan in/on maize at medium high altitude hills of Meghalaya. Indian J Pl Protec 20(2):195-197

Suganya Kanna S, Karuppuchamy P, Kuttalam S, Chandrasekaran S (2007) Harvest time residues of acetamiprid 20 SP in cotton. Pestology 31(8):28-30
Tanwar RS, Handa SK (1998) Persistence, translocation and metabolism of endosulfan residues in Pigeonpea (Cajanus cajan L. Mill sp.). Pestic Res J 10(1):73-79

Vicente A, Yolando P (2004) Determination of pesticides and their degradation products in soil: critical review and comparison of methods. Trend Anal Chem 23(10-11):772-789

World Health Organization (2004) Heptachlor and heptachlor epoxide in drinking water. Background document for development of WHO Guidelines for Drinking-Water Quality. WHO/SDE/WSH/ 03.04/99. WHO, Geneva 